\title{
СОЦИАЛЬНО-ЭКОНОМИЧЕСКОЕ РАЗВИТИЕ МАГАДАНСКОЙ ОБЛАСТИ: РЕТРОСПЕКТИВНЫЙ АНАЛИЗ (1990-2018 гг.)
}

\author{
Н. В. Гальцева, О. С. Фавстрицкая, О. А. Шарыпова \\ ФГБУН Северо-Восточный комплексный научно-исследовательский институт \\ им. Н. А. Шило ДВО РАН, г. Магадан \\ E-mail: galtseva@neisri.ru,favstritskaya@neisri.ru,sharypova@neisri.ru
}

\begin{abstract}
Проведен ретроспективный анализ социально-экономического развития Магаданской области с 1990 по 2018 г. Определены тенденции в основных видах экономической деятельности - добыче полезных ископаемых, энергетике, рыболовстве; выявлены особенности динамики ключевых демографических показателей - численности и естественного движения населения, миграции; проанализированы показатели уровня жизни - покупательная способность среднедушевых денежных доходов, ожидаемая продолжительность жизни при рождении, жилищная и продовольственная обеспеченность. Предложены возможные направления развития региона: диверсификация минерально-сырьевого комплекса, использование всех возможностей по созданию дополнительных условий для освоения ресурсного потенциала территории, повышение уровня жизни населения.
\end{abstract}

Ключевые слова: ретроспективный анализ, социально-экономическое развитие, Магаданская область, минерально-сырьевой комплекс, демография, миграция, уровень жизни, продовольственная обеспеченность, жилищный фонд.

DOI: 10.34078/1814-0998-2020-1-94-106

\section{ВВЕДЕНИЕ}

В определении перспектив социально-экономического развития региона очень важно учитывать не только имеющийся потенциал и возможности, но и накопленный за долгие годы опыт. Магаданская область была образована путем ее выделения из состава Хабаровского края в декабре 1953 г., но освоение территории началось еще в 1929 г. Период активного планового заселения территории небольшой частью завербованных вольнонаемных рабочих и заключенными, а также колонистами и спецпоселенцами области пришелся на 1929-1960 гг. (Навасардов, 1997). С 1960 г., с постепенным переходом на использование вольнонаемной рабочей силы началось активное формирование постоянного населения. Период активного экономического роста в области выпал на 1960 1990 гг. Благополучным годом, завершающим период плановой экономики, можно считать 1990-й. Как область преодолела трудности перехода к рыночным условиям, с какими результатами в ключевых сферах деятельности пришла к 65-летнему юбилею?

(C) Гальцева Н. В., Фавстрицкая О. С., Шарыпова O. A., 2020

\section{МАТЕРИАЛЫ И МЕТОДЫ ИССЛЕДОВАНИЯ}

Цель исследования заключалась в определении тенденций и особенностей в социальноэкономическом развитии Магаданской области за 1990-2018 гг. На основе ретроспективного анализа оценены основные количественные и качественные изменения в регионе по пятилеткам и по трем направлениям: демография, экономика, уровень жизни. Реальную динамику стоимостных показателей оценивали в сопоставимых ценах к базовому году, т. е. с учетом инфляции. Эмпирической базой исследования явились данные Министерства экономического развития, инвестиционной политики и инноваций Магаданской области; Министерства природных ресурсов и экологии Магаданской области, Госкомстата России и его территориального Управления федеральной службы государственной статистики по Хабаровскому краю, Магаданской области, Еврейской автономной области и Чукотскому автономному округу, а также аналитические и практические разработки авторов.

\section{РЕЗУЛЬТАТЫ ИССЛЕДОВАНИЯ И ИХ ОБСУЖДЕНИЕ}

Демография. На наш взгляд, ключевым показателем тенденций развития региона служит динамика численности населения. Активная мигра- 
ция в регион свидетельствует о его динамичном развитии и привлекательных условиях для проживания, отток из региона является реакцией на падение объемов производства и ухудшение условий жизни. В период плановой экономики происходило интенсивное освоение недр Магаданской области, шло масштабное строительство объектов производства и социальной сферы, привлекательность региона обеспечивалась высоким уровнем жизни благодаря северным льготам и гарантиям. В этот период (1960-1990 гг.) население Магаданской области увеличилось в 2 раза.

Массовый отъезд населения региона в 90-е годы прошлого столетия (с 1990 по 2000 г. численность жителей уменьшилась в 2 раза), продолжающийся отток в текущем веке (с 2000 по 2018 г. численность снизилась еще в 1.4 раза) привели к сокращению численности населения Магаданской области в 2.7 раза (табл. 1). Население области формировалось несколькими волнами миграции, но наибольший отток населения отмечался с 1995 по 2000 г. - 64.9 тыс. чел., основной причиной оттока населения было ухудшение экономической ситуации в области. На сегодня регион является одним из самых малочисленных среди субъектов РФ (83-е место в РФ из 85 регионов, с долей населения $0.09 \%$ от общероссийской численности; в 1990 г. - 77-е место из 89 , с долей населения $0.26 \%$ соответственно).

Негативная тенденция оцениваемого периода касается также доли пенсионеров в численности населения, которая увеличилась с 12\% в 1990 г. до $32 \%$ в 2018 г. (см. табл. 1).

Период 1990-2018 гг. (см. табл. 1) характеризуется не только устойчивым снижением численности постоянного населения области и занятых в экономике, но и сохраняющимся отрицательным миграционным сальдо. В связи с уменьшением численности населения за оцениваемый период в 2.7 раза практически в такой же пропорции снизилось и отрицательное миграционное сальдо с 7.8 тыс. чел. в 1990 г. до 2.7 тыс. чел. в 2018 г. Тем не менее по итогам 2018 г. не только среди регионов Дальневосточного федерального округа (ДФО), но и всех субъектов России Магаданская область имеет самый высокий коэффициент отрицательного миграционного сальдо.

В миграционном обмене с регионами России сохраняется отрицательное сальдо миграции. Среди выбывающих за пределы области наибольшей популярностью пользуются территории Центрального, Южного и Сибирского федеральных округов. Миграционный отток приводит к устойчивому сокращению собственных демографических ресурсов. В последние годы отмечается приток в регион трудовых мигрантов из стран ближнего зарубежья - Украины, Казахстана, Узбекистана, Киргизии, Республик Молдова и Беларусь и др.
Экономика. Комплексным показателем, характеризующим уровень экономического развития и результаты деятельности всех хозяйствующих субъектов региона, является валовой региональный продукт (ВРП). С 1995* по 2018 г. ВРП Магаданской области в текущих рыночных ценах увеличился в десятки раз, однако в сопоставимых ценах его рост составил лишь 6.7\%, что закономерно, учитывая произошедший спад промышленного производства и снижение численности занятых в экономике; в то же время производство среднедушевого ВРП в сопоставимых ценах за 1995-2018 гг. выросло на 30\%, что обусловлено главным образом оттоком населения.

Около 50\% ВРП области обеспечивают отрасли промышленного производства - добыча полезных ископаемых, производство и распределение электроэнергии, рыболовство.

Богатейшая минерально-сырьевая база Магаданской области предопределила направление хозяйственной деятельности территории. Развитие всех остальных отраслей промышленности было и остается подчинено масштабам производства в базовой горнодобывающей отрасли.

С 1928 г. в области добыто более 3.2 тыс. т 3олота, более 15 тыс. т серебра, 72.5 тыс. т олова, 744 т кобальта, более 85 млн т угля (Гальцева и др., 2018). С 2012 г. в регионе возобновлена добыча свинца (попутно при освоении месторождений серебра): за 2012-2018 гг. добыто около 30 тыс. т (Прусс, Шарыпова, 2019). Регион продолжает и в современных условиях специализироваться на добыче полезных ископаемых: 3олота, серебра, свинца, каменного угля, общераспространенных полезных ископаемых.

Снижение объемов добычи в начале 90-х гг., кроме объективных причин (ухудшение горногеологических условий), было вызвано структурной перестройкой экономики в целом и отрасли в частности: начался этап приватизации и дробления крупных государственных добывающих предприятий, самостоятельного изыскания финансовых ресурсов для организации производства, неплатежей между участниками производственного процесса. Объемы золотодобычи снижались до 1996 г. Рост добычи золота с 1997 г., преимущественно рудной, был обусловлен вводом крупного месторождения Кубака, в период отработки которого (с 1997 по 2002 г.) доля рудной добычи начала превосходить долю россыпной. Позже добыча несколько лет носила паритетный характер, затем доля россыпного вновь возросла. С 2003 г. наступает период падения объемов добычи вплоть до 2008 г., что происходит вследствие отработки лучших запасов россыпного золота по горногеологическим характеристикам (среднее содер-

*В 1990 г. показатель ВРП органами статистики не рассчитывался. 


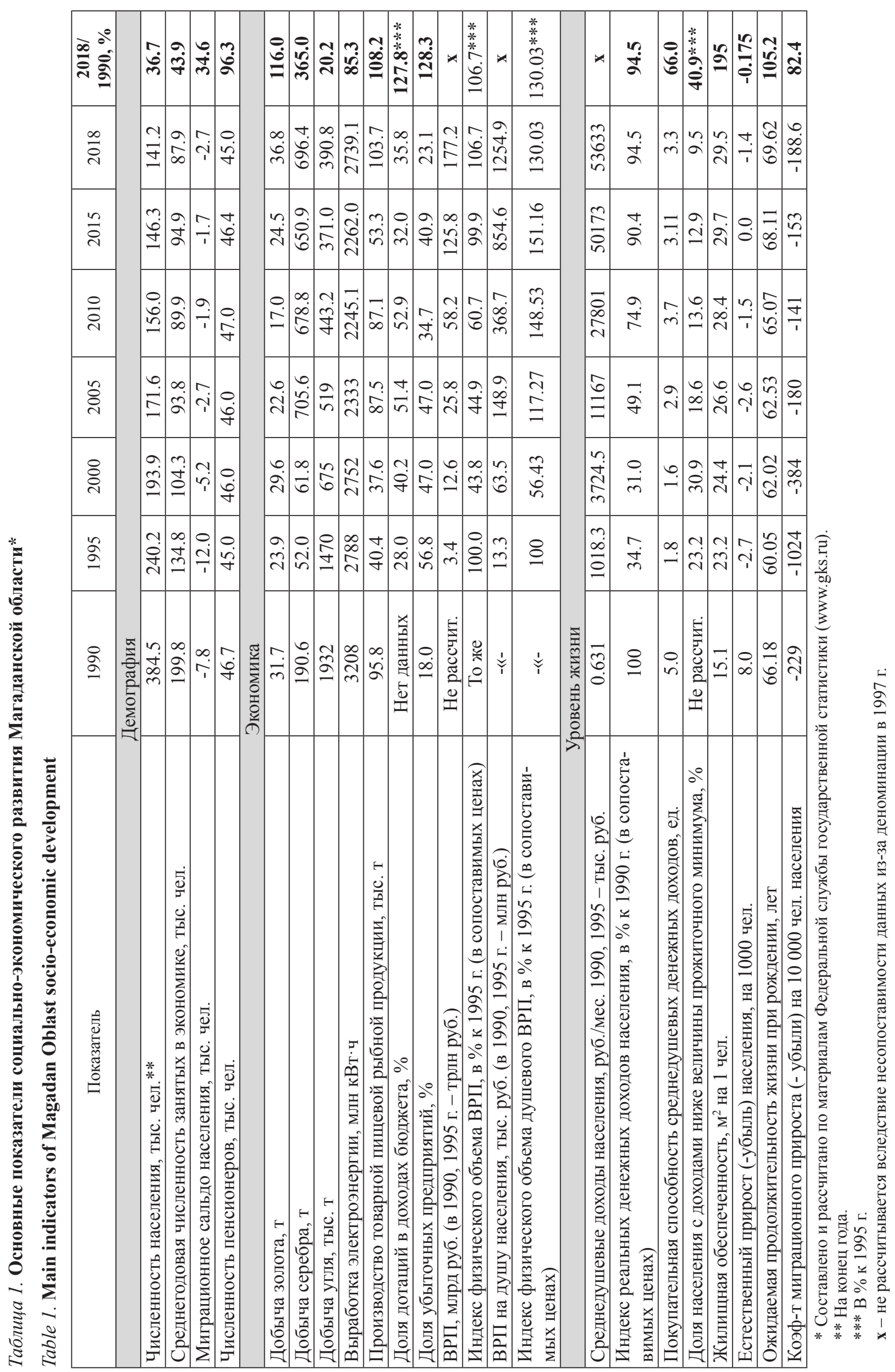


жание золота составляет менее 1 г/ $\mathbf{M}^{3}$ песков про-

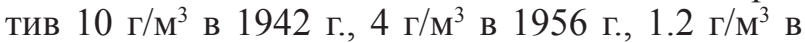
1992 г.), а также месторождений в освоенных районах территории (Гальцева, 2009). Начинается масштабная разработка рудных месторождений, в связи с чем добыча рудного золота в отдельные годы превосходит объемы россыпного.

На фоне падения золотодобычи в регионе с 2003 г. компенсирующим фактором выступает существенный рост объемов добычи серебра (рис. 1, б), начавшийся после ввода в отработку крупных золото-серебряных и серебро-золотых месторождений Дукат, Лунное, Арылах. Магаданская область с 2003 г. и по настоящее время остается лидером по добыче серебра среди регионов России (более $60 \%$ от общероссийского объема добычи). Очевидно, что рост добычи серебра на фоне масштабного снижения золотодобычи с 2003 по 2008 г. главным образом сдержал темпы падения социально-экономических показателей региона, а не обусловил их рост.

На территории области в 1998 г. с открытием Колымского аффинажного завода (производительность 40-50 т аффинированного золота «9999» в слитках и $120-150$ т серебра «9995») был создан замкнутый цикл оборота золота: лицензирование пользованием недрами - добыча металла - переработка на ЗИФ - аффинаж. Но, к

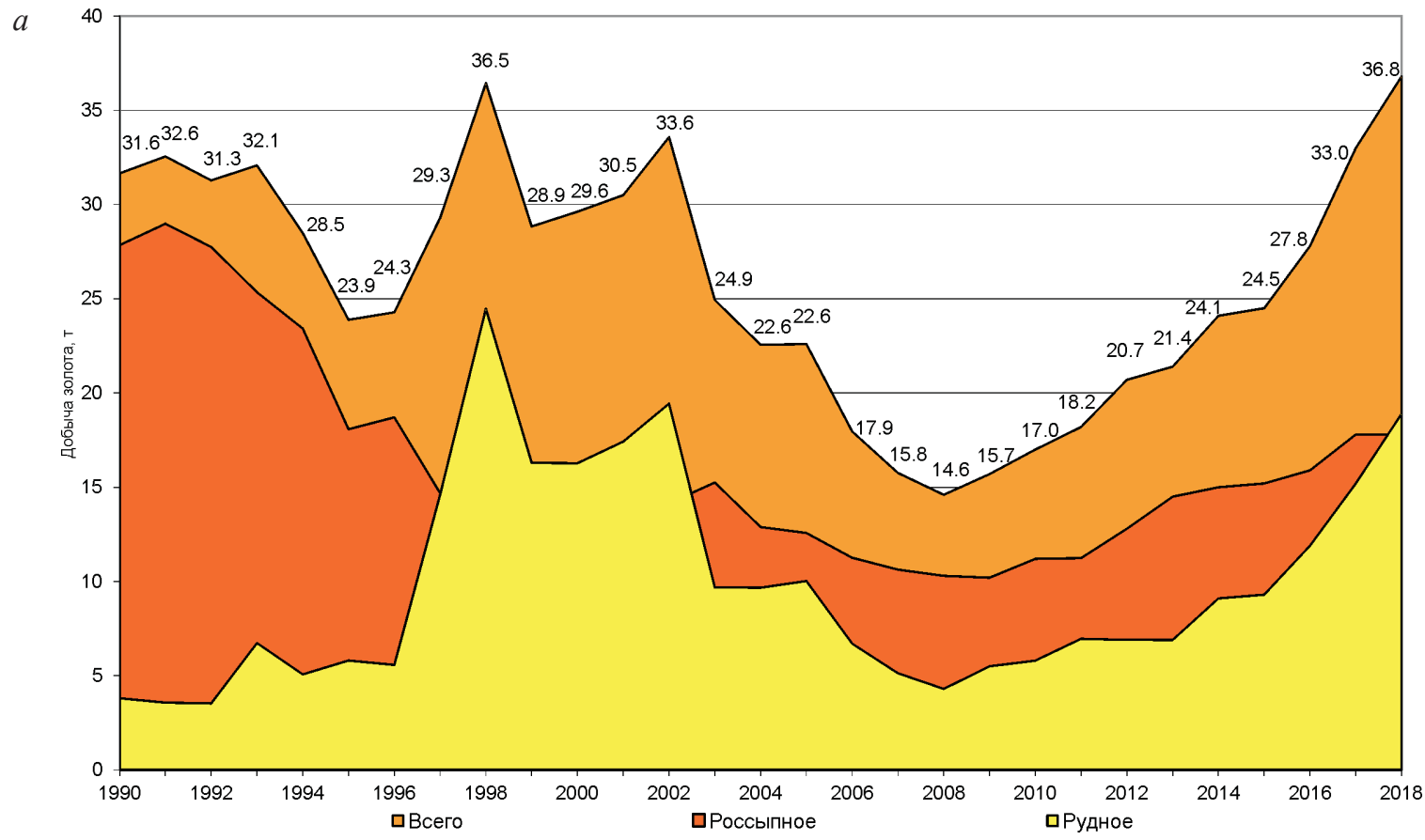

$\sigma$

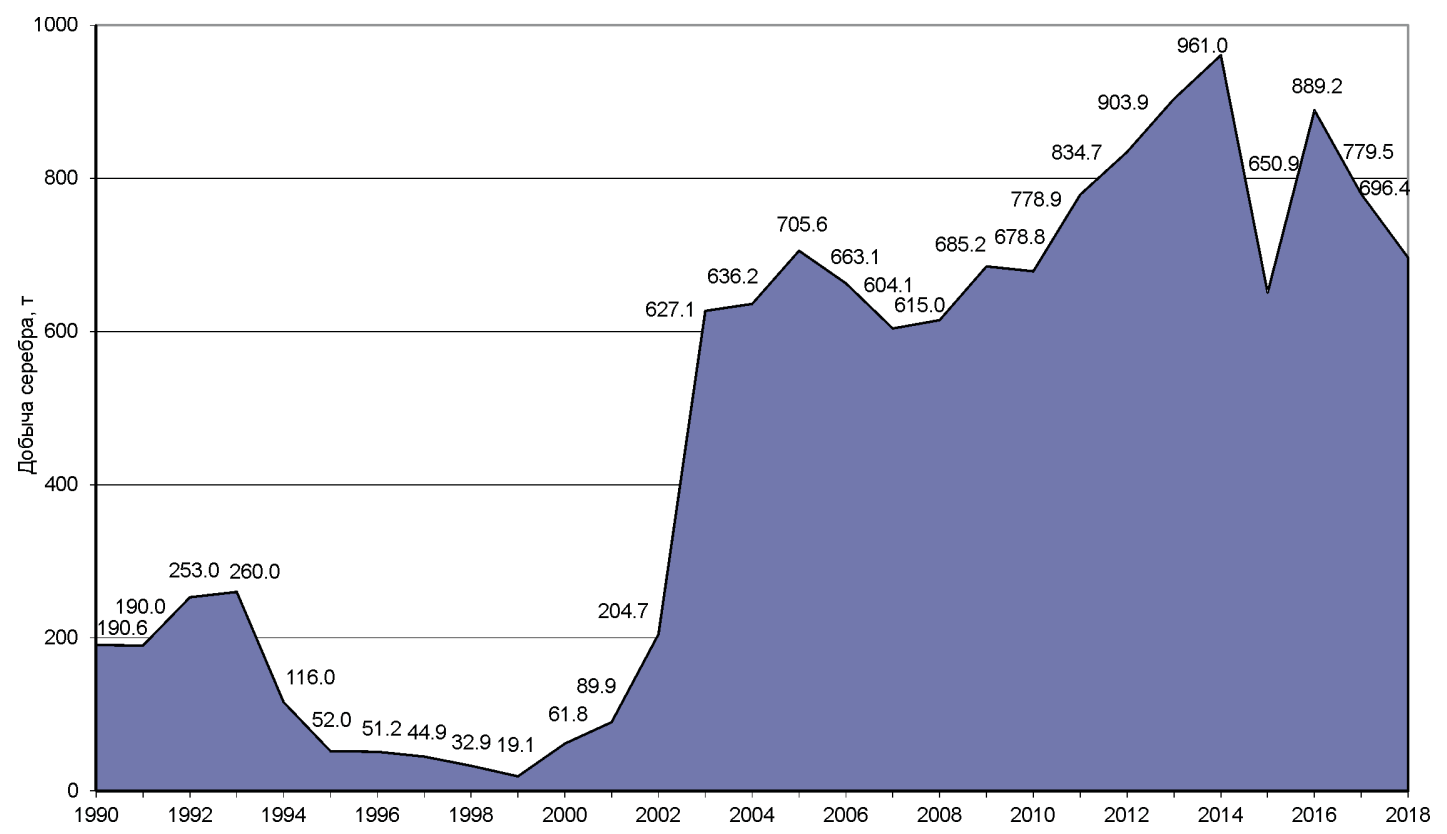

Puc.1. Добыча золота (a) и серебра (б) в Магаданской области в 1990-2018 гг., т

Fig. 1. Gold (a) and silver (б) mining in Magadan Oblast in 1990-2018, tons 
сожалению, в силу ряда причин в 2015 г. работа завода была приостановлена.

С 2009 г. рост золотодобычи в регионе возобновился преимущественно за счет россыпей. В 2018 г. в Магаданской области объем добычи золота составил около 37 т (с преобладанием рудного), что является лучшим показателем территории за оцениваемый период (см. рис. $1, a$ ).

По добыче золота область лидирует среди субъектов Дальневосточного федерального округа, а в целом по России занимает 2-е место после Красноярского края. В планах на 2019 г. 40 т золота (15.9 т россыпного и 24.1 т рудного). За 11 мес 2019 г. добыто 43.7 т золота, что свидетельствует о завершении многолетнего спада производства и начале системного роста объемов 30лотодобычи. Точками роста золотодобычи являются рудные месторождения Наталка и Павлик.

В Магаданской области в течение всего периода промышленного освоения, кроме благородных металлов, добывался уголь. Поскольку его потребление ограничено региональным спросом, его добыча снизилась еще в большей степени, чем золота. Связано это с тем, что сокращение масштабов золотодобывающей отрасли, а также обслуживающих производств привело не только к снижению объемов потребления тепла предприятиями, но и к закрытию многих поселков Магаданской области, отапливаемых местным углем. Поэтому объемы производства относительно 1990 г. снизились в 4.9 раза (см. табл. 1). Соотношение долей привозного и местного угля в суммарном потреблении изменилось в сторону увеличения доли привозного - в 1.9 раза. Таким образом, была утрачена доля местного рынка в размере $19.6 \%$ (в 1990 г. за счет собственного производства удовлетворялось $80 \%$ общего объема внутреннего потребления, в 2018 г. - 60.4\%).

Второй базовой отраслью экономики области является энергетика (производство и распределение электроэнергии и воды) с долей в объеме промышленного производства 15-35\%. Энергетическая система Магаданской области - локальная и не входит в Единую энергосистему России. Основной производитель электроэнергии - Колымская ГЭС, кроме того, электроэнергию вырабатывают Магаданская ТЭЦ и Аркагалинская
ГРЭС. В 2003 г. решался вопрос о судьбе УстьСреднеканской ГЭС - достраивать ее или подвергнуть процессу консервации. Было принято обоснованное решение продолжить строительство, и в настоящее время в эксплуатацию введены уже три гидроагрегата мощностью 310.5 МВт.

Потребителями электроэнергии, произведенной на территории, являются население и предприятия Магаданской области и Оймяконский улус Республики Саха (Якутия). В 2018 г. генерирующими мощностями области произведено 2739.1 млн кВт·ч электроэнергии, что ниже уровня 1990 г. на 14.6\%. Дальнейший рост выработки электроэнергии ожидается после строительства линии электропередачи до Чукотского автономного округа.

Третья по объему выпускаемой продукции в стоимостном выражении - пищевая промышленность, основой которой служит рыбная отрасль, ее доля в общем объеме промышленной продукции составляет 7-16\%.

С 1990 по 1995 г. произошло резкое сокращение (в 2 раза) показателей рыбохозяйственного комплекса области на фоне ухудшения сырьевой базы традиционных объектов промысла. Многие рыбодобывающие компании с устаревшим оборудованием не смогли пережить кризис (Акулич, 2011). С 2005 г. в показателях рыбодобычи региона наблюдается положительная тенденция (см. табл. 1). По итогам 2018 г. объемы добычи и производства товарной пищевой рыбной продукции превзошли показатели 1990 г. Такая положительная динамика позволяет обеспечить население региона качественной рыбной продукцией, среднедушевое потребление которой максимальное среди всех субъектов РФ.

Перспективы развития рыбодобычи связаны с сохранением объемов добычи и переработки водных биологических ресурсов, с возобновлением промысла морского зверя, с промышленным рыболовством в пресноводных водоемах бассейна p. Колыма и с развитием товарной аквакультуры.

Социально-экономический кризис при переходе к рыночной экономике затронул ведущие отрасли производства (горную, рыбную, электроэнергетику). Однако спад в этих отраслях был менее заметен, чем в сельском хозяйстве. Динамика производства основных сельскохозяйственных продуктов представлена в табл. 2.

Таблица 2. Производство основных продуктов сельского хозяйства в Магаданской области, тыс. $\mathbf{T}^{*}$ Table 2. Production of basic agricultural products in Magadan Oblast, thousand tons

\begin{tabular}{|l|r|r|r|r|r|r|r|r|}
\hline \multicolumn{1}{|c|}{ Вид продукта } & 1990 & 1995 & 2000 & 2005 & 2010 & 2015 & 2018 & $2018 / 1990, \%$ \\
\hline Картофель & 25.2 & 12.1 & 13.1 & 12.1 & 15.2 & 12.4 & 8.3 & 32.9 \\
\hline Овощи & 10.4 & 4.1 & 3.8 & 4.1 & 5.0 & 5.4 & 2.5 & 24.0 \\
\hline Скот и птица на убой (в убойном весе) & 18.6 & 3.2 & 0.5 & 0.3 & 0.8 & 0.9 & 1.0 & 5.3 \\
\hline Молоко & 62.0 & 12.4 & 5.8 & 4.5 & 5.7 & 6.0 & 6.1 & 9.8 \\
\hline Яйцо, млн шт. & 137.5 & 17.2 & 6.5 & 16.8 & 19.9 & 25.4 & 27.1 & 19.7 \\
\hline
\end{tabular}

*Составлено по материалам Федеральной службы государственной статистики (www.gks.ru). 
Несмотря на экстремальные природно-климатические условия, в Магаданской области развивается сельское хозяйство, и, хотя на долю продукции сельского хозяйства в общем объеме ВРП приходится всего лишь 2\%, эта отрасль имеет большое социально-экономическое значение, так как снабжает регион собственными свежими продуктами питания - молоком, яйцами, мясом, овощами; способствует сохранению традиционной для коренных малочисленных народов Севера отрасли - оленеводства; обеспечивает занятость сельского населения.

Уровня 1990 г. в производстве сельхозпродукции вряд ли удастся достичь. Наиболее динамично развивается в области птицеводство (см. табл. 2) - отрасль, которая обеспечивает население куриным яйцом и мясом.

На фоне возобновления роста в базовых видах экономической деятельности область остается высокодотационным регионом (см. табл. 1), однако тенденцией последних лет стало снижение доли федеральных дотаций в доходах консолидированного бюджета Магаданской области, что связано с наращиванием объемов производства в добыче полезных ископаемых.

Уровень жизни. Достигнутый уровень социально-экономического развития Магаданской области к 2018 г. характеризуется высокими рейтингами по ряду показателей: среднедушевым денежным доходам населения, зарплате, пенсиям, обеспеченности жильем и пр. (Шарыпова и др., 2019), но это не делает регион привлекательным для проживания по нескольким причинам:

1. Размер заработной платы и пенсий приведен с учетом районного коэффиџиента (70\% оклада) и северных надбавок (80\% оклада), которые по своей сути являются компенсацией за проживание в районах Крайнего Севера. Без их учета средняя заработная плата в Магаданской области $(\mathrm{MO})$ составляет в последние годы от 74 до $78 \%$ от среднероссийского уровня (рис. 2), тогда как в 19901995 гг. этот показатель был более $90 \%$. А с учетом северных доплат средняя заработная плата в области более чем в 2 раза превышала среднероссийский уровень, в последние годы это разрыв составляет 1.8 1.89 раза.

В результате в 1990 г. разница между доходами населения Магаданской области и среднероссийскими доходами составляла 2.9 раза, что делало регион привлекательным для проживания (табл. 3). В 2018 г. эта разница снизилась относительно благополучного 1990 г. в 1.8 раза и составила всего 1.6 раза, что не компенсирует в полном объеме дискомфортность проживания в северном регионе. В результате утрачены стимулирующие функции северных доплат для населения.

Несмотря на то что по законодательству система коэффициентов и надбавок продолжает действовать на территориях северных регионов, вопрос возмещения государством частным предпринимателям понесенных затрат на их выплату остается открытым. Справедливо ли, что находящиеся в неблагоприятных условиях ведения бизнеса «северные» предприятия несут на себе затраты социального характера, гарантированные государством? Такая ситуация отражается на размере собственно оплаты труда без учета северных доплат (поэтому средняя зарплата в чистом виде на $21.2 \%$ ниже среднероссийского уровня) и не способствует развитию среднего и малого бизнеса;

2. Более высокая доля экономически активного населения. На общий уровень среднедушевых доходов положительное влияние оказывает и более высокая доля экономически активного населения в регионе (на 10\% выше, чем в целом по стране), что обусловлено спецификой северного региона - более низкой долей неработающих пенсионеров относительно среднероссийского значения (см. табл. 3). В 2018 г. доля населения старше трудоспособного возраста в общей численности населения в регионе увеличилась с 1990 г. в 4.2 раза и почти достигла среднероссийского уровня;

3. Покупательная способность среднедушевых доходов жителей Магаданской области практически находится на уровне среднерос-

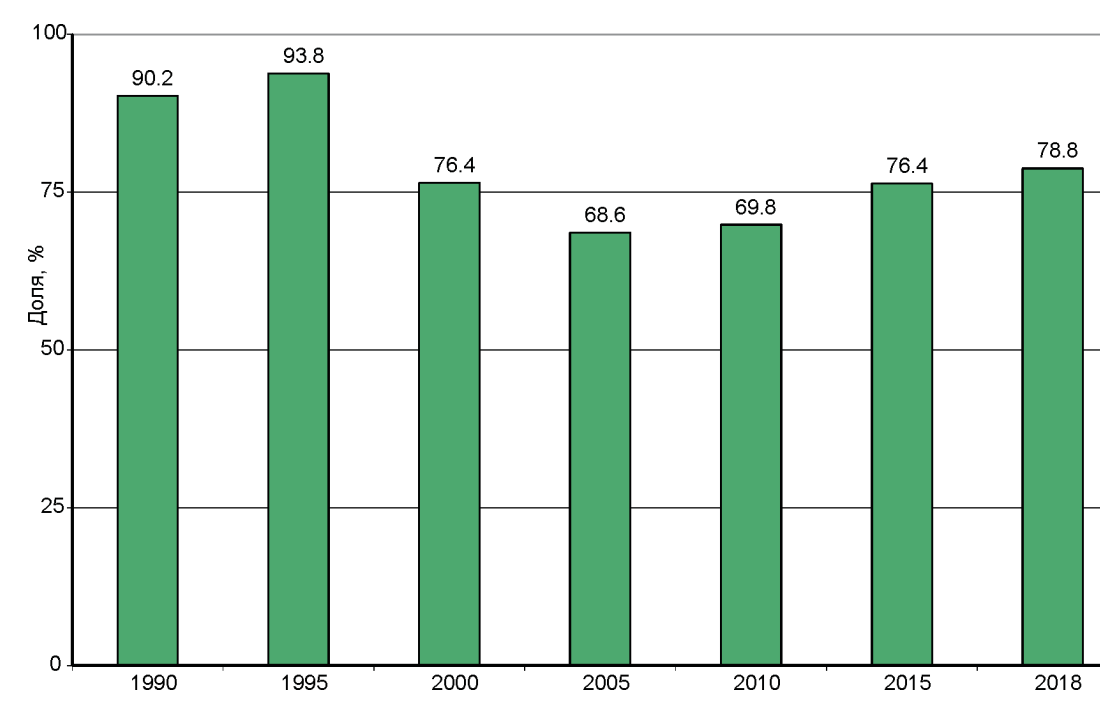

Puc. 2. Отношение средней заработной платы в Магаданской области без северных коэффициентов и надбавок к уровню заработной платы в РФ (1990 г. - в СССР)

Fig. 2. Ratio of average wages in Magadan Oblast without Northern hardship pays and wage surpluses in the Russian Federation (1990 - USSR) 
Таблица 3. Изменение показателей уровня жизни (Гальцева и др., 2017)*

Table 3. Changing living standards (Galtseva et al., 2017)

\begin{tabular}{|c|c|c|}
\hline Показатель & $\mathrm{MO}$ & PФ \\
\hline $\begin{array}{l}\text { Среднедушевые денежные доходы насе- } \\
\text { ления (в месяц; руб.; } 1990 \text { г. - тыс. руб.): } \\
1990 \text { г. } \\
2018 \text { г. }\end{array}$ & $\begin{array}{r}0.631 \\
53137 \\
\end{array}$ & $\begin{array}{r}0.217 \\
32609 \\
\end{array}$ \\
\hline $\begin{array}{l}\text { Уровень экономической активности насе- } \\
\text { ления (по данным выборочных обследо- } \\
\text { ваний населения по проблемам занято- } \\
\text { сти; в среднем за год, \%): } \\
2000 \text { г. } \\
2018 \text { г. }\end{array}$ & $\begin{array}{l}73.6 \\
62.2 \\
\end{array}$ & $\begin{array}{l}65.5 \\
51.8 \\
\end{array}$ \\
\hline $\begin{array}{l}\text { Доля населения старше трудоспособного } \\
\text { возраста (оценка на конец года, \%) } \\
1990 \text { г. } \\
2018 \text { г. }\end{array}$ & $\begin{array}{r}5.2 \\
22.0 \\
\end{array}$ & $\begin{array}{l}19.0 \\
25.9 \\
\end{array}$ \\
\hline $\begin{array}{l}\text { Динамика реальных денежных доходов } \\
\text { населения, в \% к предыдущему году: } \\
2000 \text { г. } \\
2018 \text { г. }\end{array}$ & $\begin{array}{r}100.1 \\
92.3\end{array}$ & $\begin{array}{c}113.4 \\
99.9\end{array}$ \\
\hline
\end{tabular}

*Составлено и рассчитано по материалам Федеральной службы государственной статистики (www.gks.ru).

сийского показателя - среднедушевые доходы обеспечивают 3.3 прожиточного минимума (в РФ - 3.2). При этом в регионе лимитированный выбор и высокая ценовая доступность качественных продуктов питания при ограниченных возможностях использования личного подсобного хозяйства, невысокое качество или отсутствие определенного перечня непродовольственных товаров и услуг. Это вряд ли приемлемое соотношение для северного региона. Для сравнения: в 1991 г. среднедушевые доходы в МО обеспечивали 5 прожиточных минимумов (Гальцева и др., 2015б);

4. Структура расходов населения. В 2018 г. величина потребительских расходов в Магаданской области больше среднероссийских значений всего в 1.5 раза, в то время как в 1990 г. они были выше в 2.1 раза.

Магаданская область - лидер по объему платных услуг на душу населения, этот показатель на 30\% выше средних по ДФО и на $76 \%$ выше, чем в России. В первую очередь это объясняется разницей в ценах на услуги, поскольку в силу периферийности северных территорий сектор услуг в Магаданской обла- сти развит слабо. Объем потребляемых коммунальных услуг на душу населения в Магаданской области в 1.7 раза выше средних по ДФО и в 2.3 раза выше российских показателей, что является следствием суровых природно-климатических условий, требующих дополнительных затрат на создание приемлемых условий жизни и труда.

В структуре использования денежных доходов населения как в целом России, так и Магаданской области в частности на первом месте покупка товаров и оплата услуг. В Магаданской области на данный вид использования приходится $55.3 \%$ доходов, в РФ - 75.8\% (в 1.4 раза больше). На обязательные платежи и разнообразные взносы население Магаданской области использует $14.7 \%$ своих денежных доходов - это в 1.3 раза больше, чем в РФ. На приобретение недвижимости «магаданцы» стали использовать больше своих денежных доходов - 9.6\%, что превышает среднероссийский уровень в 3 раза. На прирост финансовых активов в Магаданской области уходит $20.4 \%$ денежного дохода (в 2 раза выше среднероссийских значений) (рис. 3).

Структура расходов отражает специфику приоритетов населения северных регионов, типичным представителем которых является Магаданская область: объективно повышенные расходы на оплату услуг ЖКХ, резервирование финансовых средств для проведения «северных» отпусков и осуществления отложенных до времени

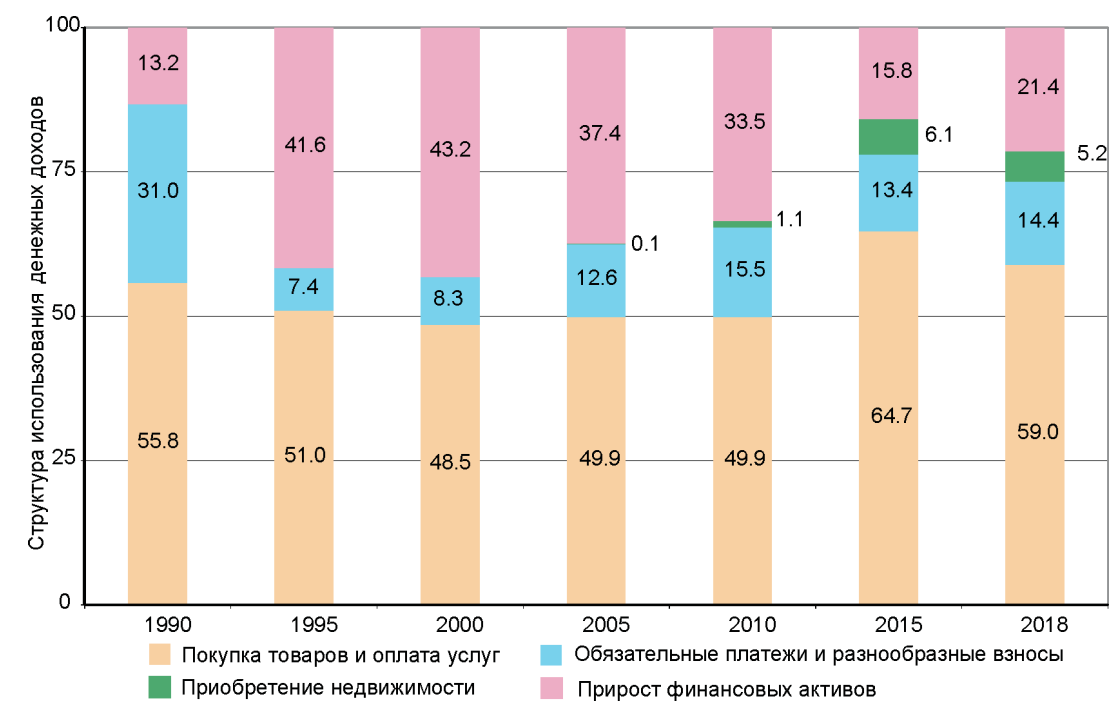

Pис. 3. Структура использования денежных доходов населения Магаданской области, \% от общего объема денежных доходов

Fig. 3. Use of Magadan Oblast population monetary income, \% of total monetary income 
покупок (что связано с бедным ассортиментом товаров в регионе, а также со стремлением сэкономить на разнице в ценах). Кроме того, накопления делаются практически каждой семьей для приобретения жилой недвижимости в регионах, более благополучных если не в экономическом плане, то, по крайней мере, в природноклиматическом. Именно по этим причинам жители северных территорий ущемляют себя в покупке качественных продовольственных и непродовольственных товаров, что отражается на качестве жизни, обусловливая непривлекательность региона для проживания при существующем уровне жизни;

5. Продовольственная обеспеченность. Сравнение фактического потребления основных продуктов питания населением области с рациональными нормами потребительской корзины позволяет определить «недопотребление» продуктов питания в целом (рис. 4, a).

«Недопотребление» основных продуктов питания в 1990 г. отсутствовало. К 1995 г. уровень «недопотребления» продуктов питания в регионе составлял примерно $30 \%$, что было связано, в первую очередь, с дефицитом продовольствия. Причины ощутимой доли «недопотребления» в 2000-2005 гг. были обусловлены дефицитом по ряду продуктов питания, а также низким уровнем доходов населения. С 1995 по 2018 г. «недопотребление» сократилось в 15 раз. В 2018 г. проблема дефицита по продуктам питания отсутствует. Доля «недопотребления» продуктов питания выражается в «недопотреблении» овощей и фруктов вследствие высокой ценовой доступности этих категорий продукции.

Продовольственная самообеспеченность региона в целом относительно фактического потребления за анализируемый период снизилась на 7\% (см. рис. 4, б). Небольшой рост уровня общей самообес-

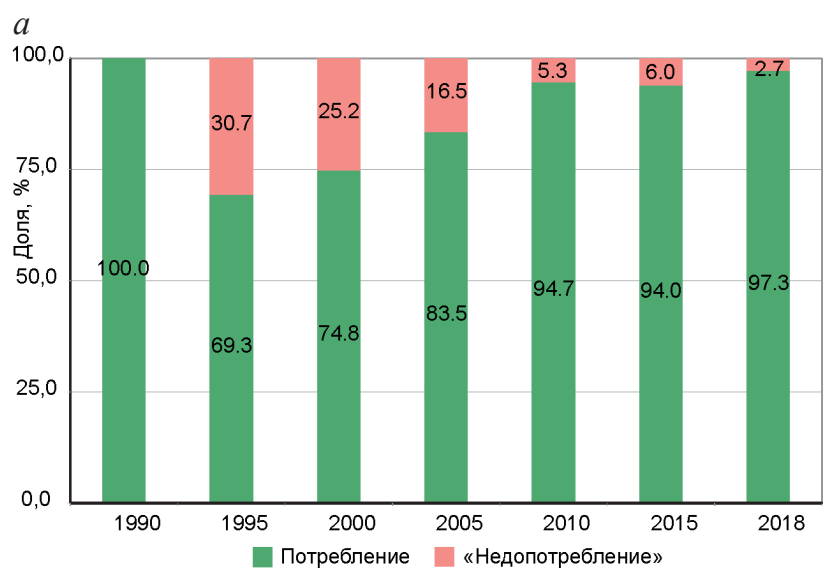

печенности начался с 2005 г. благодаря увеличению объема производства яиц, молока и мяса.

Магаданская область, с учетом специфики территориального и социально-экономического развития, характеризуется потенциальной продовольственной необеспеченностью. Причинами могут быть сбои в поставках продовольствия, рост цен на продовольственные товары и снижение покупательной способности доходов населения.

Регион обеспечивает большую часть потребности в яйце и картофеле. Показатели обеспеченности собственным мясом и молоком низкие, но имеют тенденцию к росту. Для улучшения продовольственной обеспеченности необходимо продолжать развивать те виды производства сельскохозяйственной продукции, по которым регион может перейти на полное самообеспечение или существенно сократить свою зависимость от ввоза. К таким видам продукции относятся мясо, яйцо, молочная продукция, а также овощи;

6. Уровень обеспеченности населения Магаданской области качественным жильем. Жилищный фонд (ЖФ) области является достаточно «возрастным»: до 1970 г. построено 29\% жилья, с 1971 по 1995 г. - 69\%, после 1995 г. - 2\%. Более половины ЖФ имеет износ свыше 30\%. На городскую местность приходится 93\% общей площади жилья в регионе (в том числе в г. Магадане расположено 56\%), на сельскую - 7\%.

На начало 2018 г. площадь жилых домов в Магаданской области составила 4165,3 тыс. м². За 1990-2018 гг. жилищный фонд области уменьшился на 30 \%. Выбытие жилищного фонда превышало ввод нового жилья (рис. 5).

На начало 2018 г. благоустроенным признано 92.9\% жилищного фонда области, удельный вес ветхого жилищного фонда составлял $7.1 \%$ (рис. $5, a$ ), что в 9 раз выше среднероссийского показателя.

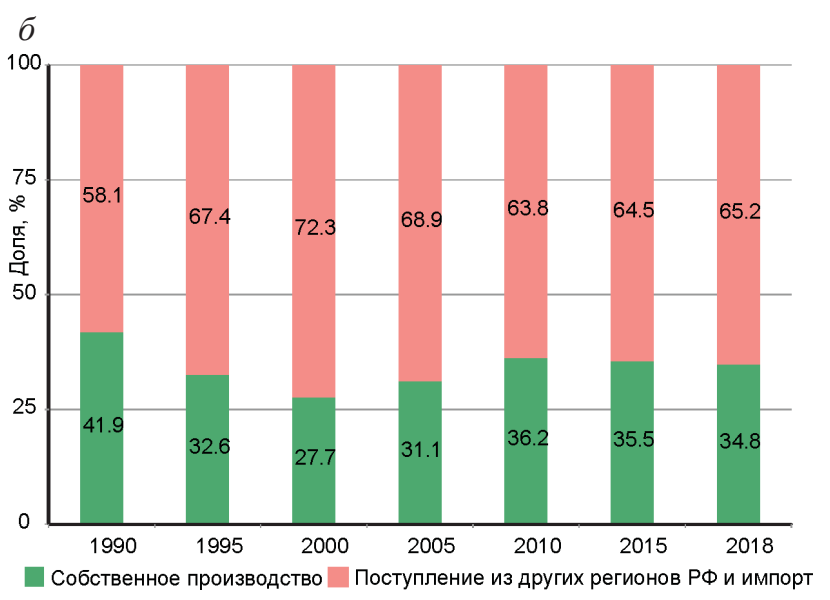

Puc. 4. Динамика общего «недопотребления» продуктов питания (a) и источники поступления основных продуктов питания (расчет исходя из фактического потребления) (б) в Магаданской области

Fig. 4. Dynamics of total "under-consumption" of food $(a)$ and sources of basic food products (calculation based on actual consumption) (б) in Magadan Oblast 

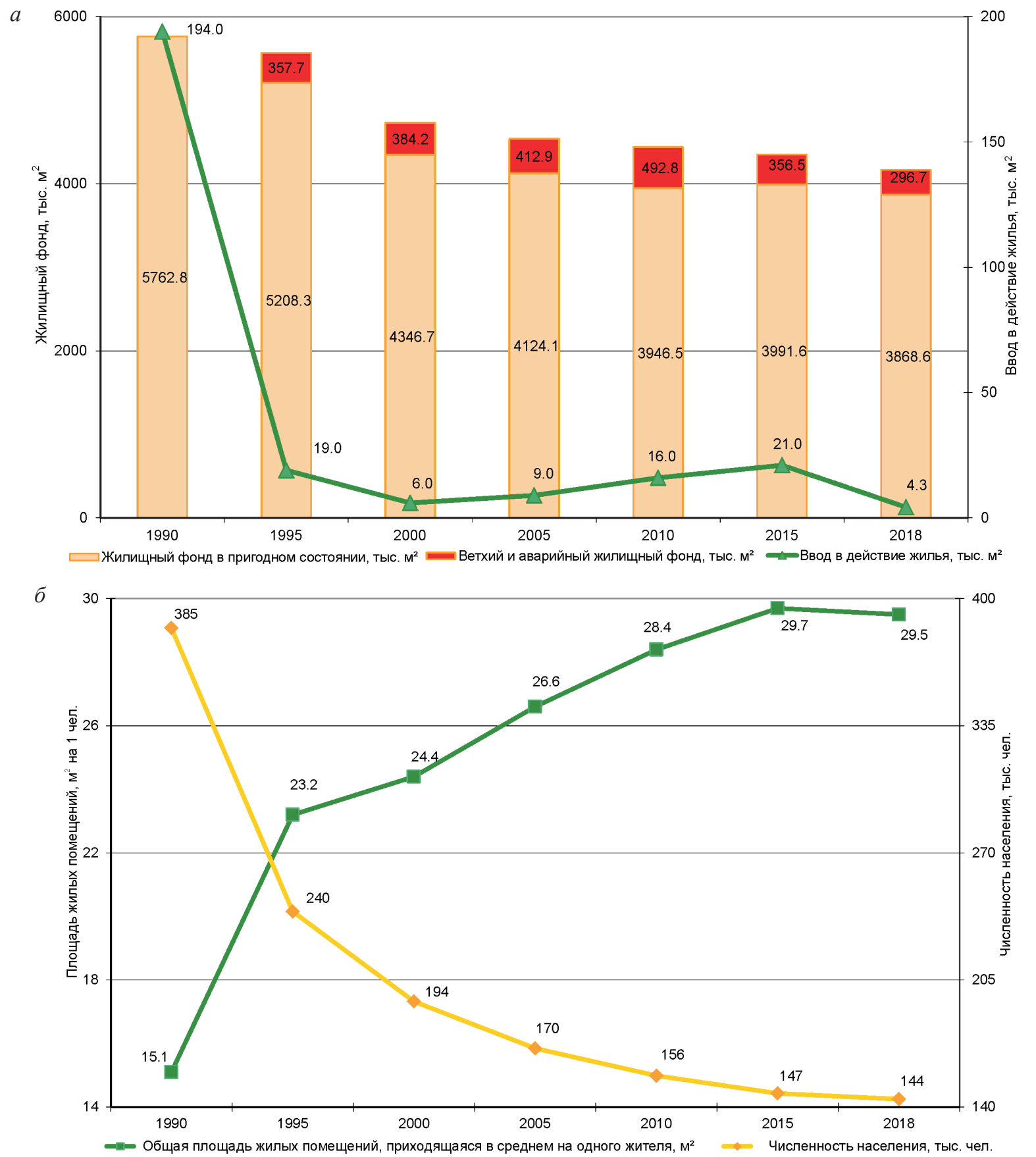

Puc. 5. Динамика показателей жилищного фонда Магаданской области (на начало года): $a$ - общий жилищный фонд в регионе; $\sigma$ - среднедушевая обеспеченность жильем

Fig. 5. Dynamics of indicators of Magadan Oblast dwelling stock (at the beginning of the year): $a$-general dwelling stock in the territory, $\sigma$ - average per capita housing

За 1990-2018 гг. изменилась структура жилищного фонда по формам собственности. Увеличилась доля жилья, находящегося в частной собственности граждан и юридических лиц. Если в 1990 г. в частной собственности было 8\% жилищного фонда, то с момента приватизации и до начала 2019 г. приватизировано 81.6\% жилищного фонда области (от общего числа жилых помещений, подлежавших приватизации).

Средняя обеспеченность жильем в России составляет $25.2 \mathrm{M}^{2}$ на 1 чел. (начало 2018 г.). Магадан- ская область относится к числу лидеров по средней обеспеченности населения области жильем, на

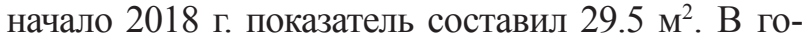
родской местности обеспеченность традиционно ниже, в сельской местности выше. В Ягоднинском городском округе обеспеченность достигает $70.27 \mathrm{M}^{2}$, в городе Магадане - $25.2 \mathrm{~m}^{2}$ (самое низкое значение). Высокие значения показателя объясняются, прежде всего, активной миграцией населения из районов области в региональный центр и в более благополучные по занятости 
и другим условиям жизни регионы страны. Формированию высокого значения показателя также способствует наличие так называемого пустующего жилищного фонда (по оценкам Фонда экономики города доля пустующего жилищного фонда в северных регионах России достигает 20\%).

Данные социологических опросов и выборочных исследований населения позволяют увидеть реальную картину в цифрах. Так, в 2016 г. на долю домохозяйств, собирающихся улучшить свои жилищные условия, приходилось 23.5\%. Основными причинами были стесненность проживания, плохое или очень плохое состояние жилого помещения. При этом из 74.8\% домохозяйств, не собирающихся улучшать свои жилищные условия, на стесненность проживания, плохое или очень плохое состояние жилого помещения сетовали $20.5 \%$.

\section{ПЕРСПЕКТИВЫ РЕГИОНАЛЬНОГО РАЗВИТИЯ}

Проблемы социально-экономического развития региона (дотационность бюджета, массовый отток населения, низкий уровень жизни населения) являются следствием моноспециализации экономики на добыче золота, а также «возрастом базовой отрасли». Кроме объективных причин их проявления, существуют и субъективные причины для условий России - переход к рыночным отношениям, снижение степени участия государства в развитии регионов.

Для роста масштабов экономики необходима модернизация ее структуры. Снизить остроту существующих проблем в регионе позволит модернизация базовой горнодобывающей отрасли на основе диверсификации. Реализация крупных инвестиционных проектов по добыче цветных металлов, железа, угля позволяет изменить траекторию регионального развития: увеличить масштабы производства, достичь бездотационного бюджета и увеличить численность населения. На следующем этапе модернизации необходимо развивать перерабатывающие отрасли, диверсифицировать экономику регионов по направлениям и глубине переработки добываемых ресурсов, а также развивать принципиально новые отрасли, например, экстремальный арктический туризм.

Согласно структуре стоимостной оценки минерально-сырьевого потенциала (прогнозные ресурсы и запасы полезных ископаемых) недра регионов, кроме добываемых благородных металлов, содержат углеводороды, цветные и черные металлы, уголь (Гальцева, 2009). Понимая необходимость диверсификации, Правительство региона способствует продвижению и реализации инвестиционных проектов по освоению новых для территорий ресурсов. В Магаданской области к числу первоочередных относятся следующие:

освоение железорудных объектов. Омолонский железорудный район в Северо-Эвенском городском округе (прогнозные ресурсы около 756 млн т железа). Для организации законченного железорудного цикла предполагается строительство металлургического комбината мощностью 4.5 млн т железа, а для обеспечения технологического процесса будут использованы коксующиеся угли близлежащих месторождений;

разработка месторождений цзетных металлов. Ороекская металлогеническая зона в Среднеканском городском округе (ресурсы меди 11 млн т), Бахапчинское месторождение и зона «Малиновая» в Ягоднинском городском округе (ресурсы вольфрама - 125 тыс. т);

добыча угля. Разработка буроугольных месторождений в Ольском городском округе: Ланковского с запасами 137 млн т угля и Мелководнинского - 505 млн т.

Цветные металлы и уголь могут представлять интерес для стран Азиатско-Тихоокеанского региона и иметь экспортную направленность. Поскольку производство экспортоориентированной продукции напрямую связано с конъюнктурой мировых рынков сырья, необходимо выбирать в качестве приоритетных проектов те, которые имеют наибольший «запас прочности» по эффективности их реализации, несмотря на возможные ресурсно-спросовые шоки мировых рынков сырья (Гальцева и др., 2015a).

Освоение ресурсного потенциала территории сопровождается рядом проблем:

естественным истощением отрабатываемых природных активов (прежде всего золотосодержащих);

высокой долей инфраструктурных объектов в проектах освоения новых ресурсов - цветных металлов, железа, угля (около 50\%);

отставанием темпов подготовки запасов от темпов их добычи, низкой долей государственных инвестиций в геологоразведочные работы, отсутствием возможности участия регионов в определении направлений расходования федеральных средств на поисково-разведочные работы;

отсутствием прав у регионов на лицензирование ключевых активов и механизмов аккумулирования доходов для новых проектов.

Перечисленные трудности обусловливают необходимость дополнительных государственных преференций. В отношении поиска новых возможностей и создания привлекательных условий для реализации ресурсного потенциала ведется работа по обоснованию включения ряда муниципальных образований региона (СевероЭвенский, Омсукчанский, Среднеканский, Сусуманский городские округа) в состав арктической зоны Российской Федерации (АЗРФ). С принятием федерального закона «О государственной поддержке инвестиционной деятельности в арктической зоне Российской Федерации» территории, относящиеся к АЗРФ, могут рассчитывать 
на комплекс мер поддержки при реализации инвестиционных проектов: льготы для резидентов АЗРФ (проект ФЗ) по налогу на прибыль, налогу на добычу полезных ископаемых, налогу на имущество, земельному налогу, по страховым взносам и таможенным платежам, по нормативному регулирование трудовых отношений.

Вложение государственных инвестиций в объекты инфраструктуры ресурсных проектов и предоставление льгот инвесторам значительно повысят их привлекательность для инвесторов и вероятность реализации.

Восстановление привлекательности северных территорий требует реанимации действовавшего в плановой экономике соотношения величины среднедушевых денежных доходов к среднероссийскому уровню, а также достижения размера среднероссийского уровня заработной платы без учета северных доплат. Для того, чтобы население без ущерба для текущего потребления имело возможность полноценно регулярно отдыхать и делать накопления на жилье в благоприятных регионах России, покупательная способность среднедушевых доходов в Магаданской области должна быть выше, как минимум, в 2 раза среднего значения по регионам России и составлять 6.6 прожиточного минимума*. Предлагаемые механизмы увеличения покупательной способности среднедушевых доходов - субсидирование затрат на основные продукты и услуги; повышение уровня зарплат за счет возмещения государством бизнесу выплачиваемых работникам северных надбавок и коэффициентов. Определенные меры в этом направлении уже приняты государством, например, для повышения мобильности и снижения затрат на проезд к месту отдыха для жителей Магаданской области введены льготные (плоские) тарифы на авиаперелет по маршрутам Магадан - Москва, Магадан - Хабаровск и в некоторые другие города России, которые ниже обычных тарифов в 2 раза.

Для обеспечения населения региона качественным жильем нами предложен инвестиционный механизм государственно-частного партнерства, который включает в себя схемы инвестирования, отличающиеся разной степенью участия государства и зависящие от двух ключевых факторов: типа населенного пункта и уровня доходов населения. Предложено, чтобы на 1 руб. частных инвестиций в жилье государством затрачивался 1 руб. бюджетных средств. Расчеты эффективности предлагаемых схем на примере Магаданской области показали, что при условии вложения 10\% населения трети прироста своих финансовых активов в инвестиционный процесс на рынке жилья доля обеспеченных качественным жильем увеличится с 46.5 до $55.5 \%$, а ин-

*B 1991 г. это соотношение составляло 5. вестиции в жилищное строительство - в 1.5 раза (Фавстрицкая, 2017).

По оценкам ученых СВКНИИ ДВО РАН, реализация пилотных инвестиционных проектов на территории Магаданской области привлечет в регион не менее 34 тыс. квалифицированных кадров. Для обеспечения этих специалистов и их семей жильем понадобится, по самым скромным подсчетам, 1500 тыс. м² комфортного современного жилья.

Правительства РФ и Магаданской области ведут активную политику по улучшению условий жизни населения и производственной деятельности в регионе. Так, например, следует отметить снижение тарифов на электроэнергию с 2017 г. для предприятий на 23\% - до 4 руб. за 1 кВт · ч и с 2020 г. для населения на $30 \%$ - до 3.65 руб. за 1 кВт · ч.

\section{ЗАКЛЮЧЕНИЕ}

С 1990 г. Магаданская область претерпела много изменений в социально-экономическом развитии. Переход к рыночной экономике в 1990-х гг. оказал чрезвычайно негативное влияние на все сферы социальной и экономической жизни территории. Произошло свертывание масштабов промышленного освоения области, что в свою очередь вызвало значительный миграционный отток населения и резкое снижение уровня жизни. Темпы снижения экономических, социальных и демографических показателей были чрезвычайно высоки и в основной массе значительно превышали средние значения по России. В это время область в связи с выделением из ее состава Чукотского автономного округа потеряла около половины своей территории и четверть населения.

Экономическое и социальное развитие области в 2000-е гг. было обусловлено необходимостью преодолеть последствия кризиса 90-х гг. Увеличение социального и экономического потенциала территории путем реализации приоритетных национальных проектов, модернизации и строительства новых добывающих и обрабатывающих производств, инфраструктуры, мощностей при эффективном использовании ресурсов являлось главной задачей развития области в начале XXI в. и остается актуальным в настоящее время.

Моноспециализация Магаданской области на добыче благородных металлов, несмотря на высокий рейтинг среди добывающих регионов, не способствует закреплению населения и бездотационному бюджету. Для изменения социальноэкономической ситуации необходима реализация крупномасштабных инвестиционных проектов, направленных на диверсификацию экономики региона.

Анализ динамики численности и структуры населения и трудовых ресурсов Магаданской области показал, что с 1990 по 2019 г. территория 
потеряла 243 тыс. чел., т. е. население области уменьшилось в 2.7 раза. В структуре мигрирующих основную долю занимает трудоспособное население, что привело к увеличению доли нетрудоспособного населения с 5.2\% в 1990 г. до $22 \%$ в 2019 г.

Причины отрицательного миграционного сальдо с сохраняющейся тенденцией увеличения оттока населения из Магаданской области связаны с низким уровнем жизни в регионе. Недостаток рабочей силы покрывается потоком трудовой миграции из других регионов и стран, использованием вахтового метода на крупных ресурсных проектах.

Ресурсный базис экономики Магаданской области претерпел следующие изменения: преобладание россыпного золота (1990-1997, 20042017 гг.), преобладание рудного золота (19972003, 2018 г.), масштабная добыча серебра (с 2003 г. по настоящее время). Истощение ресурсной базы золота, ухудшение характеристик отрабатываемых и подготавливаемых запасов и несвоевременный ввод рудных месторождений привели к обвальному снижению добычи золота с 33.6 (2002 г.) до 14.6 т (2008 г.). Рост цены на золото, а также удвоение курса доллара к рублю (2014 г.) повысили привлекательность золотодобычи, что в итоге привело к началу освоения крупных рудных месторождений и увеличению объемов россыпной золотодобычи.

Объективные причины и предпосылки формируют начало следующего этапа развития ресурсного базиса, основанного на поддержании масштабов золотодобычи и диверсификации (цветные металлы, железо, уголь).

Анализ современного состояния продовольственного обеспечения Магаданской области показал, что регион обеспечивает себя в полном объеме только рыбопродукцией, в большем объеме яйцом и картофелем. По таким видам продовольствия, как мясо и мясопродукты, растительное масло, сахар, фрукты, область полностью зависит от ввоза их из других регионов или импорта. В то же время у Магаданской области есть потенциальная возможность повысить уровень продовольственной обеспеченности за счет развития собственного производства таких видов сельскохозяйственной продукции, как мясо и мясопродукты, овощи, молоко. Проблема физической доступности продовольствия в регионе в целом уже не так актуальна, как 5-10 лет назад. Большую важность приобретает сегодня проблема ценовой доступности ряда важнейших продуктов хорошего качества для здорового питания. Частичное решение этой проблемы возможно за счет развития сельского хозяйства при государственном софинансировании, а также за счет увеличения покупательной способности доходов населения посредством повышения уровня оплаты труда в государственном и муниципальном секторе, косвенного регулирования цен на товары первой необходимости.

Оценивая перспективу жилищной обеспеченности, необходимо учитывать приоритеты пространственного развития региона. Реализация крупных сырьевых, энергетических и транспортных проектов придадут импульс развитию области. Это важно не только для социальноэкономического развития региона, но и для соблюдения геополитических интересов России в части закрепления населения в регионе.

Экономическое и социальное развитие региона в дальнейшем будет определяться внешними и внутренними условиями и факторами. К внешним факторам относятся: изменение цен на золото и серебро, тарифная политика естественных монополий, изменения в налоговом законодательстве, инфляционные процессы и др. Внутренние факторы, определяющие основные тенденции и целевые параметры развития экономики: демографическая ситуация, состояние трудовых и природных ресурсов, создание благоприятных условий для предпринимательской деятельности, рост благосостояния населения и др.

Учитывая богатый ресурсный потенциал Магаданской области, который формируют, кроме золота, серебра и угля, цветные металлы, железо, углеводороды и общераспространенные полезные ископаемые, с большой уверенностью можно утверждать, что и в обозримой перспективе экономика будет основываться на горнодобывающей отрасли.

\section{ЛИТЕРАТУРА}

Акулич О. В. Жизненный цикл рыбной отрасли Магаданской области // Проблемы современной экономики. 2011. № 1 (37). С. 286-290.

Гальцева Н. В., Прусс Ю. В., Шарыпова О. А. Перспективы использования ресурсного потенциала отходов горных производств Магаданской области // Горный журнал. 2018. № 4. С. 45-50. DOI: 10.17580/ gzh.2017.04.08

Гальиева Н. В., Фавстрицкая О. С., Шарыпова $O$. $A$. Перспективы производства экспортоориентированной продукции в Магаданской области // Вестник СВНЦ ДВО РАН. 2015а. № 4. С. 101-111.

Гальиева Н. В. Предпосылки и перспективы реструктуризации экономики Магаданской области. М. : КомКнига, 2009. 320 c.

Гальиева Н. В., Фавстриикая О. С., Шарыпова $O$. $A$. Социально-экономические факторы миграционных процессов в Магаданской области // Региональные проблемы. 2015б. Т. 18, № 3. С. 23-34.

Гальиева Н. В., Фастриикая О. С., Шарыпова $O$. $A$. Уровень жизни населения северных и арктических территорий Дальнего Востока России // Региональная экономика: теория и практика. 2017. Т. 15. Вып. 1. С. 85-100.

Навасардов С. М. Демографическая ситуация и социальные последствия экономических реформ в Магаданской области // Социологические исследования. 1994. № 7. С. 48-52. 
Проблемы и перспективы социально-экономического развития Магаданской области / Н. В. Гальцева, О. В. Акулич, Г. Н. Ядрышников, О. А. Шарыпова, Е. М. Шершакова, О. С. Фавстрицкая; [отв. ред. Н. А. Горячев, Н. В. Гальцева]; СВКНИИ ДВО РАН. Магадан : ООО «Полиарк», 2008. 331 с.

Прусс Ю. В., Шарыпова О. А. Проблемы минерально-сырьевых регионов. Магаданская область // Минеральные ресурсы России. Экономика и управление. 2019. № 6. С. 20-24.
Фавстрицкая О. С. Модернизация инвестиционного механизма жилищных рынков в депрессивных северных регионах (на примере Магаданской области) / отв. ред. Н. В. Гальцева; СВКНИИ ДВО РАН. Магадан : Экспресс-полиграфия, 2017. 151 с.

Шарыпова О. А., Гальцева Н. В., Фавстрицкая $O$. $C$. Рейтинг социально-экономического положения муниципальных образований Магаданской области (2007-2018 гг.) // Вестник СВНЦ ДВО РАН. 2019. № 4. C. 95-108.

Поступила в редакиию 15.01.2020 г.

Поступила после доработки 17.01.2020 2.

\title{
SOCIO-ECONOMIC DEVELOPMENT OF MAGADAN OBLAST: RETROSPECTIVE ANALYSIS (1990-2018)
}

\begin{abstract}
N. V. Galtseva, O. S. Favstritskaya, O. A. Sharypova
North-East Interdisciplinary Scientific Research Institute n. a. N. A. Shilo, FEB RAS, Magadan

Retrospective analysis of social and economic development of Magadan Oblast from 1990 till 2018 was carried out. Trends in the main economic activities (mining, energy, fishery) have been identified; the dynamic peculiarities of key demographic indicators (population size and natural movement, migration) have been identified; the indicators of living standards (purchasing power of the per capita monetary income, life expectancy at birth, housing and food supply) have been analyzed. Possible directions of regional development are proposed: diversification of the natural resources sector, use of all opportunities to create additional conditions for exploring the resource potential of the territory, improvement of living standards for the population.
\end{abstract}

Keywords: retrospective analysis, socio-economic development, Magadan Oblast, natural resources sector, demography, migration, standard of living, food supply, dwelling stock.

\section{REFERENCES}

Akulich, O. V., 2011, Life Cycle of Fishing Industry of Magadan Oblast, Problems of Modern Economy, 1 (37), 286-290 [In Russian].

Favstritskaya, O. S., 2017, Modernization of Housing Market Investment Mechanisms in Depressed Areas of the North (Magadan Oblast), Ed. N. V. Galtseva, NEISRI FEB RAS, Magadan, Epress-Poligrafiya [In Russian].

Galtseva, N. V., 2009, Preconditions and Prospects of Restructuring of Magadan Region Economics, Moscow, KomKniga [In Russian].

Galtseva, N. V.; Akulich, O. V.; Yadryshnikov, G. V.; Sharypova, O.A., Shershakova, Ye.M., Favstritskaya, O.S., 2008, Problems and Prospects of Social and Economic Development of Magadan Oblast, Eds. N. A. Goryachev, N. V. Galtseva, NEISRI FEB RAS, Magadan, Poliark [In Russian].

Galtseva, N. V.; Favstritskaya, O. S.; Sharypova, O. A., 2015, Prospects of Export-Oriented Production in Magadan Oblast, Vestnik NESC FEB RAS, 4, 101-111 [In Russian].

Galtseva, N. V.; Favstritskaya, O. S.; Sharypova, O. A., 2015, Socio-Economic Factors of Migratory Processes in Magadan Oblast, Regional Problems, 18, 3, 23-34 [In Russian].

Galtseva, N. V.; Favstritskaya, O. S.; Sharypova, O. A., 2017, Living Standards of the Population in the Northern and Arctic Areas of Russia's Far East, Regional Economics : Theory and Practice, 15 (1), 85-100 [In Russian].

Galtseva, N. V.; Pruss, Yu. V.; Sharypova, O. A., 2018, Prospects for Utilization of Resource Potential of Mining Waste in Magadan Oblast, Gornyi Zhurnal, 4, 45-50 [In Russian], DOI:10.17580/gzh.2017.04.08.

Navasardov, S. M., 1994, Demographic Situation and Social Consequences of Economic Reforms in Magadan Oblast, Sociological Research, 7, 48-52 [In Russian].

Pruss, Yu. V.; Sharypova, O. A., 2019, Problems of Mineral Regions, Magadan Oblast, Mineral Resources of Russia. Economics \& Management, 6, 20-24 [In Russian].

Sharypova, O. A.; Galtseva, N. V.; Favstritskaya, O. S., 2019, Rating of Socio-Economic Situations in Magadan Oblast Municipalities (2007-2018), Bulletin of the NorthEast Scientific Center, 4, 95-108 [In Russian]. 